Mar. Drugs 2011, 9, 242-255; doi:10.3390/md9020242

Article

\title{
The New Carotenoid Pigment Moraxanthin Is Associated with Toxic Microalgae
}

Olga Mangoni ${ }^{1}$, Concetta Imperatore ${ }^{2}$, Carmelo R. Tomas ${ }^{3}$, Valeria Costantino ${ }^{2}$, Vincenzo Saggiomo ${ }^{4}$ and Alfonso Mangoni ${ }^{2, *}$

1 Dipartimento delle Scienze Biologiche, Università di Napoli Federico II, Via Mezzocannone 8, 80134 Napoli, Italy; E-Mail: olga.mangoni@unina.it

2 Dipartimento di Chimica delle Sostanze Naturali, Università di Napoli Federico II, via D.

Montesano 49, 80131 Napoli, Italy; E-Mails: cimperat@unina.it (C.I.);

valeria.costantino@unina.it (V.C.)

3 Center for Marine Science, University of North Carolina at Wilmington, 5600 Marvin K. Moss Lane, Wilmington, NC 28409, USA; E-Mail: tomasc@uncw.edu

4 Stazione Zoologica "A. Dohrn", Villa Comunale I, 80121 Napoli, Italy; E-Mail: saggiomo@szn.it

* Author to whom correspondence should be addressed; E-Mail: alfonso.mangoni @unina.it;

Tel.: +39-081-678-532; Fax: +39-081-678-552.

Received: 22 December 2010; in revised form: 25 January 2011 / Accepted: 4 February 2011 /

Published: 10 February 2011

\begin{abstract}
The new pigment "moraxanthin" was found in natural samples from a fish mortality site in the Inland Bays of Delaware, USA. Pure cultures of the species, tentatively named Chattonella $c f$. verruculosa, and natural samples contained this pigment as a dominant carotenoid. The pigment, obtained from a $10 \mathrm{~L}$ culture of $C$. $c f$. verruculosa, was isolated and harvested by HPLC and its structure determined from MS and 1D- and 2D-NMR. The data identified this pigment as a new acylated form of vaucheriaxanthin called moraxanthin after the berry like algal cell. Its presence in pure cultures and in natural bloom samples indicates that moraxanthin is specific to $C$. $c f$. verruculosa and can be used as a marker of its presence when HPLC is used to analyze natural blooms samples.
\end{abstract}

Keywords: Chattonella $c f$. verruculosa; Raphidophyceae; toxic algae; carotenoids; moraxanthin 


\section{Introduction}

Phytoplankton, unicellular photosynthetic microorganisms, are ubiquitous in all aquatic environments. As primary producers, they are responsible for nearly half of the global primary production of organic carbon [1]. Photosynthesis, the process whereby energy is absorbed by pigments in algae and transformed into chemical energy, relies on the presence of energy trapping pigments. The main pigments, chlorophylls, carotenoids and phycobilins, absorb Photosynthetically Available Radiation (PAR) from 400-700 nm wavelengths [2]. However, pigments may also serve several functions including metabolic regulation, light harvesting (antenna pigments), electron donation or acceptance (in reaction centers), and photoprotection. The combination of different pigments and functions result in maximum efficiency and economy [3-6]. The kind of pigments produced and their relative proportions characterize the different phytoplankton groups.

In recent years, high performance liquid chromatography (HPLC) has been used to estimate phytoplankton composition by identifying photosynthetic pigments. Some pigments found exclusively in particular algal classes or genera may serve as useful taxonomic markers [7-13]. Such indicator pigments are termed 'finger prints'. Pigment analyses offer a valuable technique in oceanography for mapping phytoplankton populations and monitoring their abundance and composition [14-17].

Phytoplankton blooms occur naturally in coastal waters particularly during spring and summer seasons. However, a small number of microalgae are harmful, and although each individual is small, they may occur in huge numbers known as blooms [18-21]. Among the estimated phytoplankton species, about $7 \%$ (300 species) are known to produce red tides and of those, only $2 \%$ are actually harmful or toxic [22]. In marine and brackish water environments, most toxic species belong in the Dinophyceae, but also the Diatomophyceae, Haptophyceae, Raphidophyceae, and Cyanophyceae comprise toxic species [23-28]. The algal toxins may cause damage to other flora and fauna directly or they may accumulate through the food web in e.g., shellfish or finfish, thereby causing harm to their predators including humans [29-34]. Harmful algal blooms (HABs) are an ever more frequent phenomenon expanding in coastal regions on a world scale [35-38]. These have received much attention from researchers and local regulatory authorities due to their impact on the ecosystem and human health, influencing local economic issues [39].

Monitoring of coastal waters for harmful species is costly and labor-intensive and the possibility to recognize a potentially harmful algal species by means of chemical or biochemical analyses significantly reduces the time and costs of such monitoring. The one caveat is that the analysis, pigment or biochemical, involves a species specific marker for the HAB species in question [40]. Pigment signatures in the study of HABs have been very limited, particularly in monitoring programs $[33,41,42]$.

During the summer period of 2000, ten fish mortality events occurred from unidentified causes in the Inland Bays of Delaware, USA. During the final fish-killing event of 28 August, 2000, over two million menhaden (Brevoortia tyrranus) perished when a bloom of an unidentified microalgal flagellate was observed [36]. This flagellate, accompanied by the presence of a potent neurotoxin, was tentatively called Chattonella cf. verruculosa since it resembled a fish killing species found in Japan thought to be of the class Raphidophyceae. Since none of the previously described Raphidophyceae 
completely agreed with the molecular features (18S rDNA; 16S rDNA) [43,44], further studies are underway to define its taxonomic position.

This work describes the isolation and structural elucidation of a new pigment (1) found in C. $c f$. verruculosa cultures and in natural samples where this species was dominant, which has been called moraxanthin after the berry like algal cell (Figure 1). Moraxanthin, which is a new acylated form of vaucheriaxanthin (2), is unique to $C$. $c f$. verruculosa, indicating that it can be used as a marker of its presence when HPLC analyses of natural blooms are performed.

Figure 1. Structures of moraxanthin (1) and vaucheriaxanthin (2).

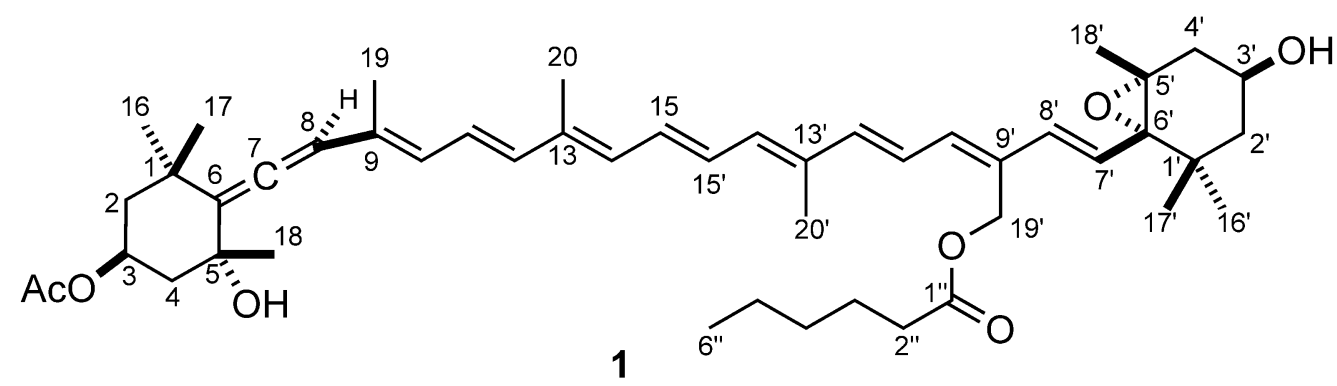

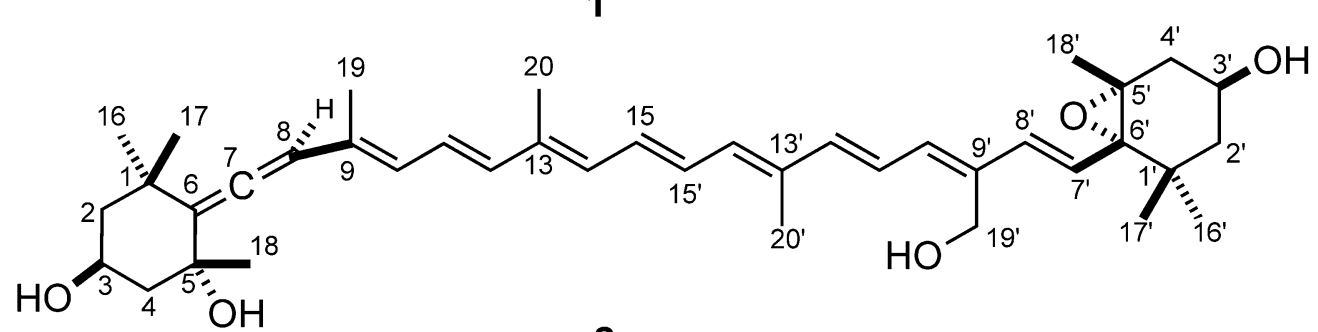

2

\section{Results and Discussion}

The chromatogram of the pigments of the C. cf. verruculosa culture showed a major peak (Figure 2, peak 4), whose retention time (Table 1) and UV spectrum (Table 1 and Figure 3) did not fit those of any known pigments, although the UV spectrum clearly showed the pigment to be a carotenoid.

Figure 2. HPLC absorbance chromatogram of the extract from cultured $C$. cf. verruculosa.

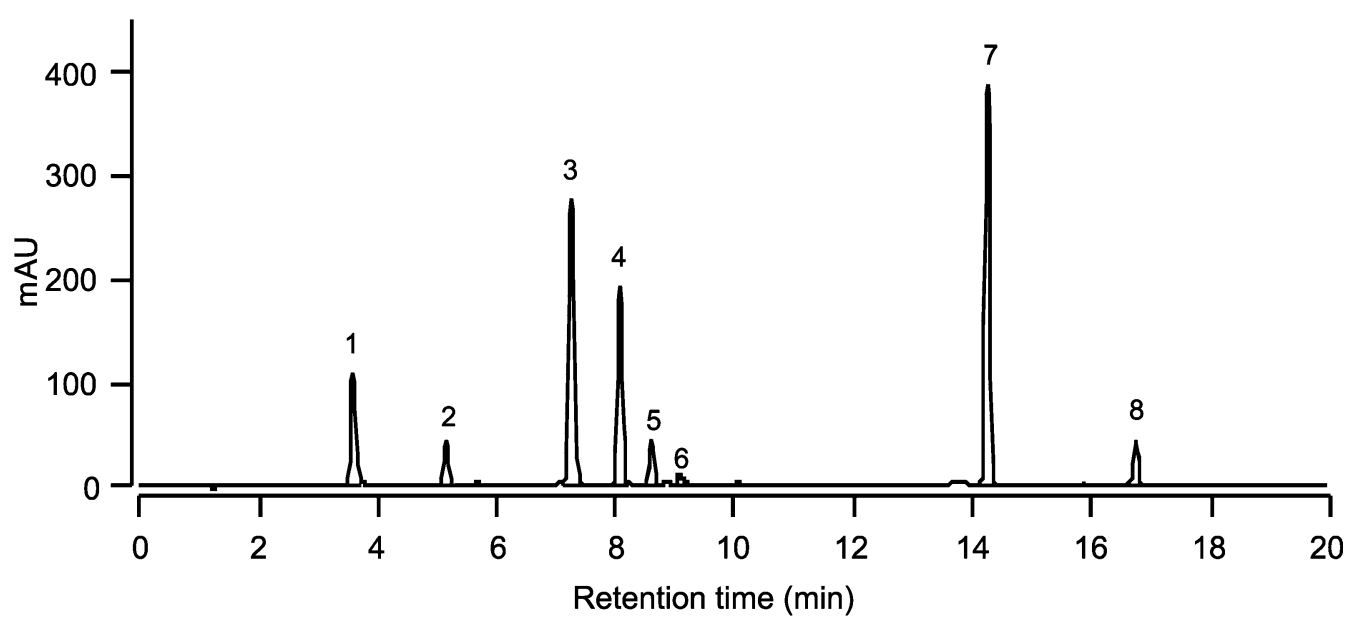


Figure 3. UV spectrum of moraxanthin $1(\mathrm{EtOH})$.



Table 1. Total pigments found in C. $c f$. verruculosa with relative retention times and specific absorption maxima.

\begin{tabular}{llllll}
\hline Peak No. & Pigments & Retention time (min) & \multicolumn{3}{l}{ Absorption maxima (nm) } \\
\hline 1 & Chlorophyll $c_{1}+c_{2}\left(\mathrm{Chl} c_{1}+c_{2}\right)$ & 3.59 & 445 & 583 & 634 \\
2 & Unknown (RT 5.15) & 5.15 & 423 & 446 & 476 \\
3 & Diadinoxanthin (Dd) & 7.24 & 422 & 446 & 475 \\
$\mathbf{4}$ & Moraxanthin & $\mathbf{8 . 0 7}$ & $\mathbf{4 2 1}$ & $\mathbf{4 4 4}$ & $\mathbf{4 7 2}$ \\
5 & Diatoxanthin (Dt) & 8.60 & 426 & 451 & 478 \\
6 & Zeaxanthin (Zea) & 9.08 & & 449 & 477 \\
7 & Chlorophyll $a(\mathrm{Chl} a)$ & 14.25 & 432 & 617 & 665 \\
8 & $\beta$-carotene $(\beta-\mathrm{car})$ & 16.75 & & 450 & 478 \\
\hline
\end{tabular}

The new pigment was then isolated to determine its structure by spectroscopic (MS and NMR) means. A large-scale $(10 \mathrm{~L})$ culture of $C$. $c f$. verruculosa was grown, and harvested by continuous flow centrifugation into an algal pellet and supernatant. The algal pellet $(4 \mathrm{~g})$ was extracted exhaustively with $\mathrm{MeOH}$, and the extract was subjected to repeated HPLC separation, yielding $1.1 \mathrm{mg}$ of the pure carotenoid moraxanthin (1). When re-injected in the same HPLC conditions as for the chromatogram in Figure 2, the isolated compound 1 showed retention time and UV spectrum identical to that of peak 4. Compound 1 showed a $[\mathrm{M}+\mathrm{Na}]^{+}$pseudomolecolar ion peak in the ESI high-resolution mass spectrum at $m / z$ 779.4879, in accordance with the formula $\mathrm{C}_{48} \mathrm{H}_{68} \mathrm{NaO}_{7}$. Compared to the $\mathrm{C}_{40}$ carotenoid skeleton, this formula contains eight additional carbon atoms. In addition, the ESI mass spectrum also contained a peak at $m / z 663\left(\mathrm{C}_{42} \mathrm{H}_{56} \mathrm{NaO}_{5}\right.$, $\left.\left[\mathrm{M}+\mathrm{Na}-\mathrm{C}_{6} \mathrm{H}_{12} \mathrm{O}_{2}\right]^{+}\right)$, which can be accounted for by the in-source loss of hexanoic acid.

Most of the information used for structure elucidation came from one- and two-dimensional NMR spectroscopy. The general features of the proton NMR spectrum $\left(\mathrm{C}_{6} \mathrm{D}_{6}\right)$ resembled those of carotenoids, with several olefinic protons between $\delta 6$ and $\delta 7$, and 10 methyl singlets between $\delta 1.87$ 
and 1.08. However, one of the ten methyl signals $(\delta 1.74)$ was part of an acetyl group, as shown by its correlation peak with the carbonyl carbon atom at $\delta 169.2$ in the HMBC spectrum. Other notable features of the proton NMR spectrum were (i) the $\mathrm{AB}$ system at $\delta 5.13$ and $5.07\left(\mathrm{H}_{2}-19^{\prime}\right)$ of an oxymethylene group, (ii) two oxymethine protons at $\delta 5.69(\mathrm{H}-3)$ and $\delta 3.78\left(\mathrm{H}-3^{\prime}\right)$, a methyl triplet at $\delta 0.78\left(\mathrm{H}_{3}-6 "\right)$ and a methylene triplet at $\delta 2.14\left(\mathrm{H}_{3}-2 "\right)$, indicative of an acyl chain and (iv) an olefinic proton singlet at $\delta 6.03(\mathrm{H}-8)$, which showed correlation peaks in the HMBC spectrum with two non-protonated carbon atoms at $\delta 202.1$ (C-7) and 117.8 (C-6), and was therefore part of an allene system. The observed structural features were suggestive of a structure similar to vaucheriaxanthin (2), but a direct comparison of spectral data was hindered by the presence of the two additional acyl groups. A detailed analysis of the correlation peaks observed in the COSY, HSQC, and HMBC (Figure 4) spectra demonstrated that the planar structure of moraxanthin is indeed the same as that of vaucheriaxanthin, except for the presence of an acetyl group at position 3 and a hexanoyl group at position 19'.

Figure 4. ${ }^{1} \mathrm{H}-{ }^{13} \mathrm{C}$ long range couplings evidenced by the HMBC spectrum of moraxanthin (1).

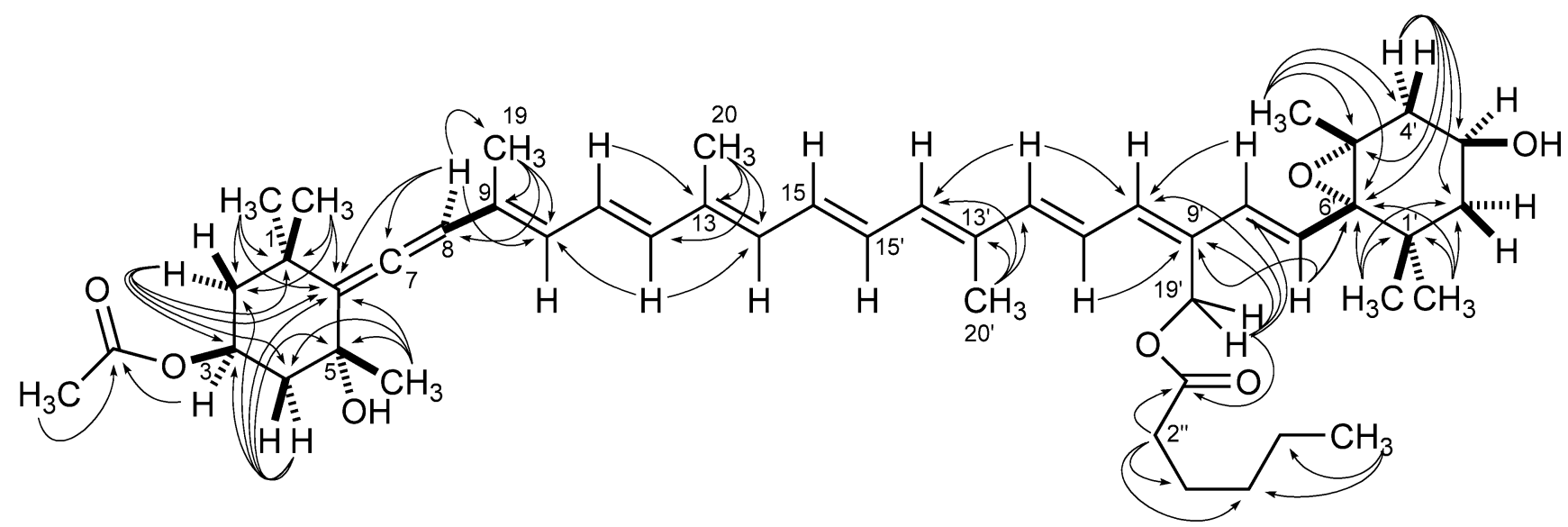

In addition to all the expected geminal and vicinal couplings, the COSY spectrum revealed several proton-proton long-range couplings. Among them, the quite large W couplings of $\mathrm{H}-2 \alpha$ with $\mathrm{H}-4 \alpha$ $(2.2 \mathrm{~Hz})$ and of $\mathrm{H}^{-} 2^{\prime} \alpha$ with $\mathrm{H}-4^{\prime} \alpha(1.7 \mathrm{~Hz})$ indicated the 1,3-diequatorial relationship of these two pairs of protons. Furthermore, the methyl protons on the polyene system showed weak correlation peaks with the olefinic protons, arising from the usual allylic ${ }^{4} J_{\mathrm{HH}}$ couplings, but also from ${ }^{6} J_{\mathrm{HH}}$ couplings $\left(\mathrm{H}_{3}-19 / \mathrm{H}-12, \mathrm{H}_{3}-20 / \mathrm{H}-15^{\prime}, \mathrm{H}_{3}-20^{\prime} / \mathrm{H}-15\right)$ and even one remarkable ${ }^{8} J_{\mathrm{HH}}$ coupling $\left(\mathrm{H}_{3}-19 / \mathrm{H}-14\right)$. To the best of our knowledge, this is the first report of a ${ }^{8} J_{\mathrm{HH}}$ coupling in a carotenoid.

The $E$ configuration of double bonds at positions 11, 15, 7', and 11' was evident from the large trans coupling constant values of the relevant protons (see Table 2). The $E$ configuration of double bonds at positions 9, 13, and 13' and the $Z$ configuration of the double bond at position 9' were determined from the ROESY spectrum, displaying correlation peaks of $\mathrm{H}_{3}-19$ with $\mathrm{H}-11, \mathrm{H}_{3}-20$ with $\mathrm{H}-15, \mathrm{H}_{3}-20$ ' with H-15', and $\mathrm{H}_{2}-9$ ' with H-11'. 
Table 2. ${ }^{1} \mathrm{H}(700 \mathrm{MHz})$ and ${ }^{13} \mathrm{C}(175 \mathrm{MHz}) \mathrm{NMR}$ data of moraxanthin $\mathbf{1}$ in $\mathrm{C}_{6} \mathrm{D}_{6}$.

\begin{tabular}{|c|c|c|c|c|c|c|c|}
\hline Pos. & & $\delta_{\mathrm{H}}(J$ in $\mathrm{Hz})$ & $\delta_{\mathrm{C}}$, mult & Pos. & & $\delta_{\mathrm{H}}(J$ in $\mathrm{Hz})$ & $\delta_{\mathrm{C}}$, mult \\
\hline 1 & & - & $35.8, \mathrm{C}$ & $1^{\prime}$ & & - & $35.2, \mathrm{C}$ \\
\hline \multirow[t]{2}{*}{2} & $\alpha$ & 2.05, ddd $(12.4,4.2,2.2)$ & $45.8, \mathrm{CH}_{2}$ & $2^{\prime}$ & $\alpha$ & 1.48, ddd $(12.8,3.3,1.7)$ & 47.1, $\mathrm{CH}_{2}$ \\
\hline & $\beta$ & $1.39, \mathrm{dd}(12.4,11.5)$ & & & $\beta$ & $1.11, \mathrm{dd}(12.8,10.2)$ & \\
\hline \multirow[t]{2}{*}{3} & & $5.69, \operatorname{dddd}(11.5,11.5,4.2,4.2)$ & $67.7, \mathrm{CH}$ & $3^{\prime}$ & & 3.78, ddddd (10.2, 8.6, 5.2, 4.3, 3.3) & $63.7, \mathrm{CH}$ \\
\hline & & & & 3'-OH & & $0.57, \mathrm{~d}(4.3)$ & - \\
\hline \multirow[t]{2}{*}{4} & $\alpha$ & 2.30, ddd $(12.8,4.2,2.2)$ & $45.5, \mathrm{CH}_{2}$ & $4^{\prime}$ & $\alpha$ & 2.24, ddd $(14.2,5.2,1.7)$ & $41.0, \mathrm{CH}_{2}$ \\
\hline & $\beta$ & $1.41, \operatorname{ddd}(12.8,11.5,1.7)$ & & & $\beta$ & $1.48, \mathrm{dd}(14.2,8.6)$ & \\
\hline 5 & & - & 72.0, C & $5^{\prime}$ & & - & 66.6, C \\
\hline $5-\mathrm{OH}$ & & $0.77, \mathrm{~d}(1.7)$ & - & & & - & - \\
\hline 6 & & - & $117.8, \mathrm{C}$ & $6^{\prime}$ & & - & $69.9, \mathrm{C}$ \\
\hline 7 & & - & 202.1, C & $7^{\prime}$ & & $6.22, \mathrm{~d}(15.7)$ & $125.9, \mathrm{CH}$ \\
\hline 8 & & $6.03, \mathrm{~s}$ & 103.3, CH & $8^{\prime}$ & & $6.63, d(15.7)$ & $134.9, \mathrm{CH}$ \\
\hline 9 & & - & $131.9, \mathrm{C}$ & $9^{\prime}$ & & - & $132.4, \mathrm{C}$ \\
\hline 10 & & $6.20, \mathrm{~d}(11.4)$ & $129.0, \mathrm{CH}$ & $10^{\prime}$ & & $6.27, \mathrm{~d}(11.6)$ & $136.3, \mathrm{CH}$ \\
\hline 11 & & $6.70, \mathrm{dd}(15.0,11.4)$ & $125.3, \mathrm{CH}$ & $11^{\prime}$ & & 6.95, dd $(14.9,11.6)$ & 124.1, CH \\
\hline 12 & & $6.46, \mathrm{~d}(15.0)$ & $137.5, \mathrm{CH}$ & $12^{\prime}$ & & $6.39, \mathrm{~d}(14.9)$ & 141.0, CH \\
\hline 13 & & - & $136.8, \mathrm{C}$ & $13^{\prime}$ & & - & $136.4, \mathrm{C}$ \\
\hline 14 & & $6.28, \mathrm{~d}(11.5)$ & $133.0, \mathrm{CH}$ & $14^{\prime}$ & & $6.27, \mathrm{~d}(11.5)$ & $134.5, \mathrm{CH}_{2}$ \\
\hline 15 & & $6.66, \mathrm{dd}(14.3,11.5)$ & $131.1, \mathrm{CH}$ & $15^{\prime}$ & & $6.60, \mathrm{dd}(14.3,11.5)$ & $130.3, \mathrm{CH}$ \\
\hline 16 & & $1.43, \mathrm{~s}$ & $29.0, \mathrm{CH}_{3}$ & $16^{\prime}$ & & $1.15, \mathrm{~s}$ & $25.2, \mathrm{CH}_{3}$ \\
\hline 17 & & $1.08, \mathrm{~s}$ & $32.1, \mathrm{CH}_{3}$ & $17^{\prime}$ & & $1.14, \mathrm{~s}$ & $29.4, \mathrm{CH}_{3}$ \\
\hline 18 & & $1.17, \mathrm{~s}$ & $30.9, \mathrm{CH}_{3}$ & $18^{\prime}$ & & $1.19, \mathrm{~s}$ & $20.0, \mathrm{CH}_{3}$ \\
\hline \multirow[t]{2}{*}{19} & & $1.78, \mathrm{~s}$ & $13.8, \mathrm{CH}_{3}$ & $19^{\prime}$ & $\mathrm{a}$ & $5.07, \mathrm{~d}(12.3)$ & $58.1, \mathrm{CH}_{2}$ \\
\hline & & & & & $\mathrm{b}$ & $5.13, \mathrm{~d}(12.3)$ & \\
\hline 20 & & $1.87, \mathrm{~s}$ & $12.7, \mathrm{CH}_{3}$ & $20^{\prime}$ & & $1.86, \mathrm{~s}$ & $12.6, \mathrm{CH}_{3}$ \\
\hline 1" & & - & $172.8, \mathrm{C}$ & Ac & $\mathrm{CH}_{3}$ & $1.74, \mathrm{~s}$ & $20.8, \mathrm{CH}_{3}$ \\
\hline 2" & & $2.14, \mathrm{t}(7.5)$ & $34.2, \mathrm{CH}_{2}$ & & $\mathrm{CO}$ & - & $169.2, \mathrm{C}$ \\
\hline 3" & & 1.55 , quintet (7.5) & $24.8, \mathrm{CH}_{2}$ & & & & \\
\hline 4" & & 1.12 , overlapped & $31.3, \mathrm{CH}_{2}$ & & & & \\
\hline $5 "$ & & 1.14 , overlapped & 22.4, $\mathrm{CH}_{2}$ & & & & \\
\hline 6" & & $0.78, \mathrm{t}(7.0)$ & $13.8, \mathrm{CH}_{3}$ & & & & \\
\hline
\end{tabular}

The ROESY spectrum also provided information on the relative configuration of the two terminal six-membered rings (Figure 5). The allene terminus is in the chair conformation, with the two W-coupled $\mathrm{H}-2 \alpha$ and $\mathrm{H}-4 \alpha$ protons in the equatorial orientation. The large coupling constants of $\mathrm{H}-3$

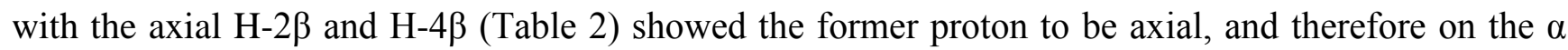
face of the ring; as a consequence, the OAc group at C-3 must be $\beta$. The ROESY correlation of the methyl protons $\mathrm{H}_{3}-19$ with $\mathrm{H}-2 \beta$ and $\mathrm{H}-4 \beta$ determined the axial chirality of the allene functionality as $R$. Finally, the ROESY correlation of $\mathrm{H}_{3}-19$ with $\mathrm{H}_{3}-18$ located $\mathrm{C}-18$ on the $\beta$ face of the ring, and therefore the $\mathrm{OH}$ group at $\mathrm{C}-5$ on the $\alpha$ face. 
Figure 5. ROESY correlations used to determine the relative configuration of moraxanthin (1).

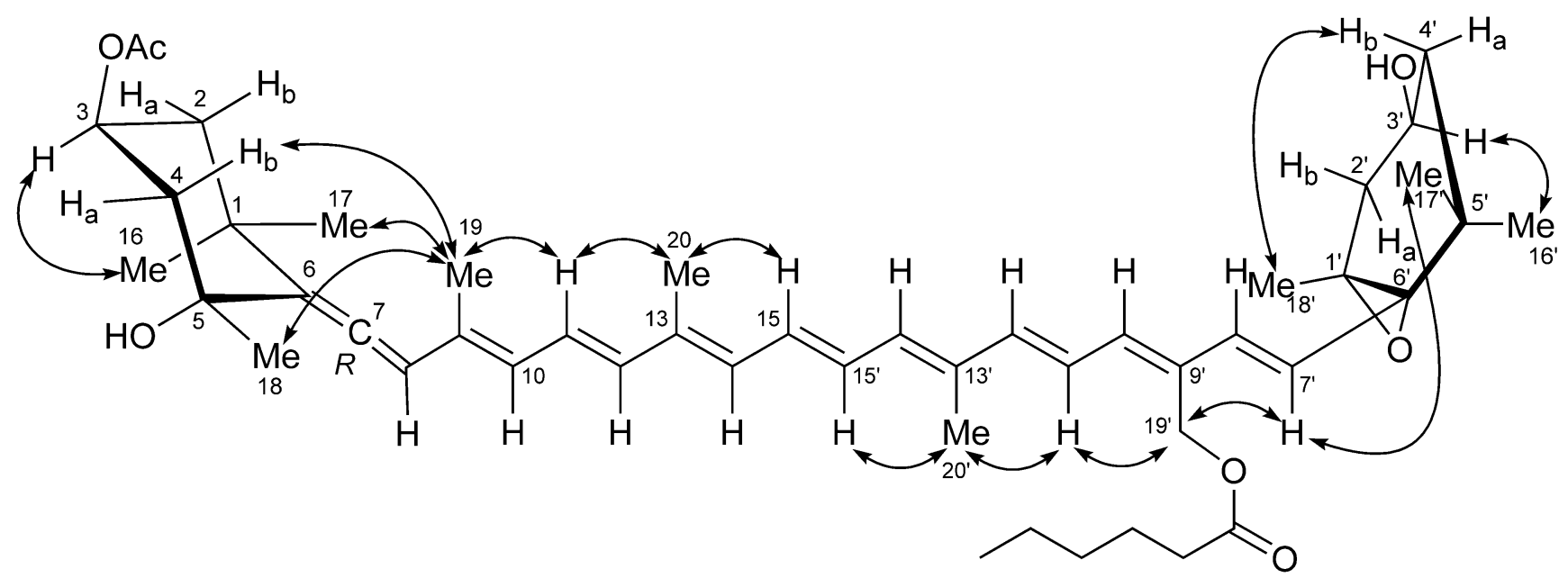

As for the other terminal ring, the $\mathrm{W}$ coupling $(1.7 \mathrm{~Hz})$ of the pseudoequatorial $\mathrm{H}-2^{\prime} \alpha$ and $\mathrm{H}-4^{\prime} \alpha$ suggests a half-chair conformation of this ring. The trans relationship between the epoxide ring and the hydroxyl group was established from the ROESY correlation peaks of the two geminal methyl groups $\mathrm{H}_{3}-16^{\prime}$ and $\mathrm{H}_{3}-17^{\prime}$ with, respectively, $\mathrm{H}-3^{\prime}$ and $\mathrm{H}^{\prime} 7^{\prime}$ (Figure 5), showing that $\mathrm{H}-3^{\prime}$ and $\mathrm{H}-\mathrm{7}^{\prime}$ are on opposite faces of the six-membered ring. This was confirmed by the prominent peak between the psudoaxial $\mathrm{H}-4 \beta$ and $\mathrm{H}_{3}-18$ in the same spectrum. The relative configuration determined for moraxanthin matches that of vaucheriaxanthin (2), and it may be assumed that also the absolute configuration of moraxanthin is the same as in vaucheriaxanthin.

Figure 6. HPLC absorbance chromatogram of natural water sample collected at the fish-kill site of Torque Canal, Delaware on 28 August 2000 during a C. cf. verruculosa bloom. The arrow indicates the moraxanthin peak.

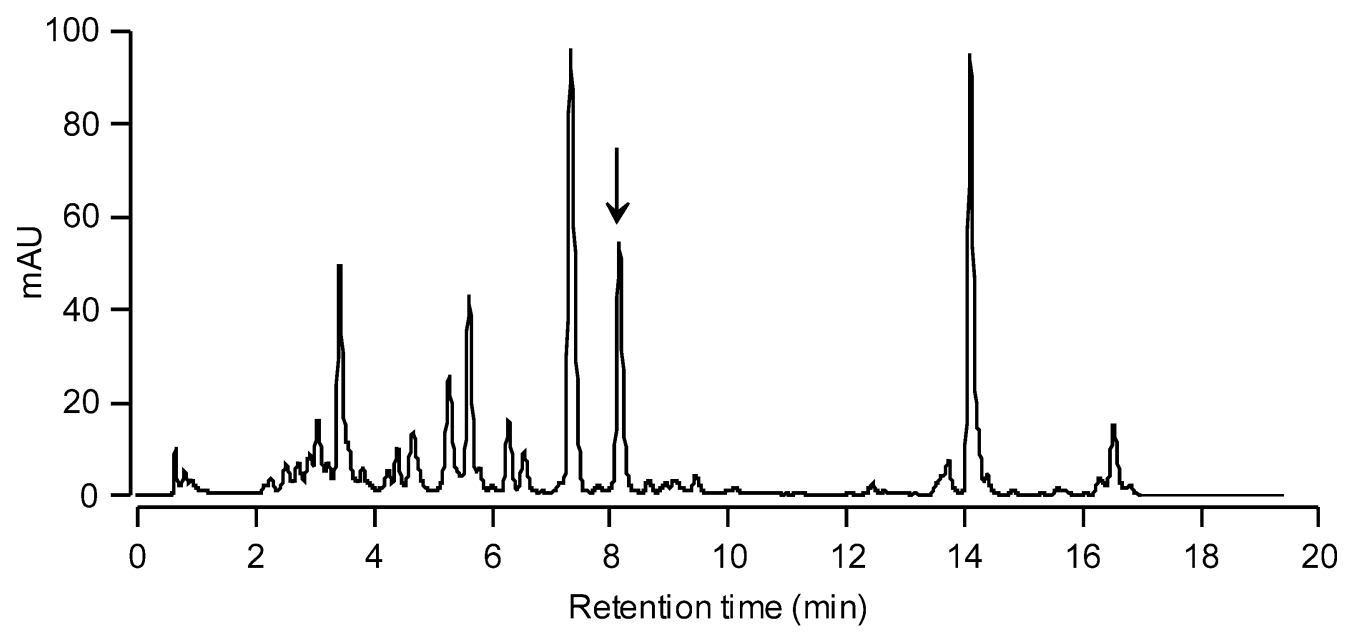

To investigate the utility of using moraxanthin as a marker for the toxic alga $C$. $c f$. verruculosa, natural bloom samples from the fish-kill site at Torque Canal, Delaware, collected on 28 August 2000 on Whatman GFF glass fiber filters and stored at $-80{ }^{\circ} \mathrm{C}$, were extracted in methanol and subjected to HPLC analysis. The HPLC chromatogram (Figure 6) definitely showed a peak for moraxanthin in the natural sample. The moraxanthin peak clearly separated from all the other pigment peaks having no 
overlap with other pigments. In addition, a peak with the same retention time and absorbance characteristics was present in the HPLC chromatogram from water samples collected in 2003-2007 at various sites in Delaware's Inland Bays where $C$. $c f$. verruculosa blooms occurred (data not shown). This shows that the HPLC analysis may provide a simple and rapid tool for detecting harmful blooms of C. cf. verruculosa.

\section{Experimental Section}

\subsection{General experimental procedures}

ESI-MS experiments were performed on an Applied Biosystem API 2000 triple-quadrupole mass spectrometer. High Resolution ESI-MS spectra were performed on a Thermo Orbitrap XL mass spectrometer. All the mass spectra were recorded by infusion into the ESI source using $\mathrm{MeOH}$ as the solvent. CD spectra were recorded in $\mathrm{MeOH}$ solution on a Jasco J-710 spectrophotometer using a $1 \mathrm{~cm}$ cell. ${ }^{1} \mathrm{H}$ and ${ }^{13} \mathrm{C}$ NMR spectra were determined in $\mathrm{C}_{6} \mathrm{D}_{6}$ solution on a Varian UnityInova spectrometer at 700 and $175 \mathrm{MHz}$, respectively; chemical shifts were referenced to the residual solvent signal $\left(\delta_{\mathrm{H}} 7.15, \delta_{\mathrm{C}}=128.0\right)$. For an accurate measurement of the coupling constants, the one-dimensional ${ }^{1} \mathrm{H}$ NMR spectra were transformed at $64 \mathrm{~K}$ points (digital resolution: $0.09 \mathrm{~Hz}$ ). Homonuclear ${ }^{1} \mathrm{H}$ connectivities were determined by COSY experiments. Through-space ${ }^{1} \mathrm{H}$ connectivities were evidenced using a ROESY experiment with a mixing time of $500 \mathrm{~ms}$. The reverse multiple-quantum heteronuclear correlation (HMQC) spectra was optimized for an average ${ }^{1} J_{\mathrm{CH}}$ of $142 \mathrm{~Hz}$. The gradient-enhanced multiple-bond heteronuclear correlation (HMBC) experiment was optimized for a ${ }^{3} J_{\mathrm{CH}}$ of $8.3 \mathrm{~Hz}$.

\subsection{Plant material}

Clonal cultures of $C$. $c f$. verruculosa were established by single cell pipette isolation from a natural bloom sample taken at the time of a fish-kill in Torque Canal, Delaware. Individually isolated cells were grown in DYV medium [43] using sea water adjusted to a salinity of 20 to match that of the sample water. Successful isolates grown in 96 well microtiter plates were stepped up in volume eventually becoming stabilized cultures maintained in $150 \mathrm{~mL}$ volumes in erlenmeyer culture flasks. All cultures were maintained at $22{ }^{\circ} \mathrm{C}$, with a fluence rate of $50 \mu$ mol. quanta $\mathrm{m}^{-2} \mathrm{~s}^{-1}$ of cool white fluorescent light and a 12:12 h (LD) cycle. For this study, culture CMS TAC1050 was used and is presently deposited in the Center for Marine Science Toxic Algal Collection housed at UNCW's marine facility. This collection of harmful species is under the direction of Dr. Carmelo Tomas, Professor of Biology and Marine Biology at the CMS location who was also the isolator of the original culture. Large volume cultivation consisting of $10 \mathrm{~L}$ batches were grown in Bellco stirred cell system under conditions mentioned above. After a growth period of 1 month, the $10 \mathrm{~L}$ culture was harvested using a Sorvall RCB-2 refrigerated centrifuge equipped with a KSB (Kendro) continuous centrifuge head. A $4 \mathrm{~g}$ (wet weight) pellet was harvested, transferred to $15 \mathrm{~mL}$ cryovials and kept frozen at $-80{ }^{\circ} \mathrm{C}$ prior to analyses for pigments. 


\subsection{Pigment analysis}

The algal pellet $(1 \mathrm{~g})$ from cultures of $C$. $c f$. verruculosa was extracted with $\mathrm{MeOH}(3 \mathrm{~mL})$, and the extract was filtered through Whatman GFF $(0.45 \mu \mathrm{m})$. A portion of extract $(500 \mu \mathrm{L})$ was added to $250 \mu \mathrm{L}$ of ion-pairing solution (1M ammonium acetate), and after 5 minutes injected to the HPLC system. Assessment of the pigment composition was performed using a Hewlett-Packard HPLC 1100 Series system, equipped with a quaternary pump system and diode array detector. Pigments were separated on a temperature-controlled $\left(20{ }^{\circ} \mathrm{C}\right)$ Hypersil MOS C8 reverse phase column (Sigma-Aldrich, $3 \mu \mathrm{m}, 100 \times 4.6 \mathrm{~mm}$ ) according to the HPLC method of Vidussi et al. [45]. The mobile phases were $\mathrm{MeOH}$ (eluent $\mathrm{A}$ ) and $\mathrm{MeOH} / 0.5 \mathrm{~N}$ ammonium acetate (7:3) (eluent $\mathrm{B}$ ). The elution gradient was kept constant at $1.0 \mathrm{~mL} / \mathrm{min}$ for $20 \mathrm{~min}$. The ratio of eluent $\mathrm{B}$ was gradually increased from 25 to $100 \%$, and then returned to the initial proportion at the end of the elution. Chlorophylls and carotenoids were detected at $440 \mathrm{~nm}$ and identified by a diode array detector $(\lambda=350-750 \mathrm{~nm}, 1.2 \mathrm{~nm}$ spectral resolution). Standards of all the known pigments were provided by International Agency for ${ }^{14} \mathrm{C}$ Determination (VKI Water Quality Institute) and calibration was performed according to Mantoura and Repeta [46].

\subsection{Analysis of algal bloom}

Samples from blooms occurring in the Delaware Inland Bays were collected and returned to the laboratory or shipped by overnight courier to UNCW CMS Laboratory. Upon arrival, the sample was processed immediately. Pigment samples were taken as natural samples filtered on Whatman GFF filters and frozen immediately in liquid nitrogen and stored in a $-80^{\circ} \mathrm{C}$ freezer until extraction and pigment analyses could be performed as described above. Species contents of the sample water were determined by direct observations using a Nikon Diaphot inverted microscope. Observations of the phytoplankton included species identification, at least to genus level of live cells, cell density estimates using standard inverted microscope techniques and extraction for lipid soluble toxins in chloroform. Preserved samples (Lugol's solution) were carefully mixed, placed into a 10 or $50 \mathrm{~mL}$ settling chamber and allowed to settle for 24 hours prior to observation. The dominant species were identified, enumerated and used to define the phytoplankton composition.

\subsection{Extraction and isolation of moraxanthin (1)}

The algal pellet $(4 \mathrm{~g})$ was extracted once with $\mathrm{MeOH}(40 \mathrm{~mL})$. The extract was dried to give a dark green oil (104 mg) which was subjected to reversed-phase HPLC separation on a Varian Prostar 210 apparatus equipped with an Varian $325 \mathrm{UV}$ detector [column: RP-18, $10 \mu \mathrm{m}, 250 \times 10 \mathrm{~mm}$; eluent: $\mathrm{MeOH} / \mathrm{H}_{2} \mathrm{O}(9: 1)$, flow $5 \mathrm{~mL} / \mathrm{min}$, UV detector set at $430 \mathrm{~nm}$ ] to give partially purified moraxanthin (3.4 mg). Further reversed phase HPLC [column: RP-18, $3 \mu \mathrm{m}, 250 \times 4.6 \mathrm{~mm}$; eluent: $\mathrm{MeOH} / \mathrm{H}_{2} \mathrm{O}$ (8:2), flow $1 \mathrm{~mL} / \mathrm{min}$, UV detector set at $430 \mathrm{~nm}$ ] gave pure moraxanthin $1(1.1 \mathrm{mg})$, whose identity was confirmed by HPLC analysis as described in Section 4.3. 


\subsection{Moraxanthin (1)}

Dark yellow oil; $\mathrm{CD}\left(\mathrm{MeOH} ; c 3.06 \cdot 10^{-6} \mathrm{M}\right): \Delta \varepsilon_{471}+9.9, \Delta \varepsilon_{446}+11.9, \Delta \varepsilon_{422}+9.0$; UV (EtOH): $\lambda_{\max }$ $\mathrm{nm}(\varepsilon)$ : 421 (89000), 444 (129000), 472 (118000); ESI MS m/z $779[\mathrm{M}+\mathrm{Na}]^{+}$; HRESIMS $\mathrm{m} / \mathrm{z}$ $779.4879[\mathrm{M}+\mathrm{Na}]^{+}$(calcd. for $\mathrm{C}_{48} \mathrm{H}_{68} \mathrm{NaO}_{7}, 779.4857$ ). For ${ }^{1} \mathrm{H}$ and ${ }^{13} \mathrm{C}$ NMR spectroscopic data, see Table 2.

\section{Conclusions}

The newly proposed toxic species $C$. $c f$. verruculosa contains a new species-specific pigment, moraxanthin (1), whose structure was established as (3S,5R,7R,3'S,5'R,6'S)-3-acetoxy-5',6'-epoxy-19'(hexanoyloxy)-6,7-didehydro-5,6,5',6'-tetrahydro- $\beta, \beta$-carotene-5,3'-diol, $\quad$ i.e., $\quad 3-O$-acetyl-19'-Ohexanoylvaucheriaxanthin. Two esterified forms of vaucheriaxanthin have been described, namely the 3-O-acetyl-19'-O-octanoate and the 3-O-acetyl-19'-O-decanoate derivatives [47]. However, none of them contains the hexanoyl residue present in moraxanthin, which therefore can be easily distinguished from these known compounds on the basis of the HPLC retention time.

New harmful species have been identified and the taxonomy of other species has been revised [48]. It is usually accepted that the routine identification of phytoplankton for monitoring studies in estuaries and coastal waters requires additional methods other than traditional microscopy, which can underestimate some taxonomic groups containing fragile or poorly differentiated small cells. In conjunction with microscopy, pigment separation using HPLC has become a more widely applied method for estimating and characterizing phytoplankton biomass and community structure [6-8].

However, algal pigments usually show complex overlapping patterns with different taxa, offering only a few unambiguous markers. In our case, $C$. $c f$. verruculosa may be readily identified in natural samples by means of HPLC chromatograms due to the distinct peak corresponding to the species-specific pigment moraxanthin described here.

\section{Acknowledgements}

The research leading to these results has received funding from the European Union's Seventh Framework Programme FP7/2007-2013 under grant agreement $\mathrm{n}^{\circ} 229893$ (NatPharma) and from grant No. 01504-07 awarded by U.S. Center for Disease Control and Prevention and North Carolina Department of Health and Human Services to Carmelo Tomas. Mass and NMR spectra were recorded at the "Centro Interdipartimentale di Analisi Strumentale", Università di Napoli "Federico II". The assistance of the staff is gratefully acknowledged.

\section{References}

1. Falkowski, P.G.; Raven, J.A. Aquatic Photosynthesis; Blackwell Science: Oxford, UK, 1997; p. 375.

2. Rowan, K.S. Photosynthetic Pigments of Algae; Cambridge University Press: Cambridge, UK, 1989. 
3. Porra, R.J.; Pfündel, E.E.; Engel, N. Metabolism and function of photosynthetic pigments. In Phytoplankton Pigments in Oceanography; Jeffrey, S.W., Mantoura, R.F.C., Wright, S.W., Eds.; UNESCO Publishing: Paris, France, 1997; pp. 85-126.

4. Scheer, H. The pigments. In Light-Harvesting Antennas in Photosynthesis. Advances in Photosynthesis and Respiration; Green, B.R., Parsons, W.E., Eds.; Kluwer Academic Publishers: Dordrecht, The Netherlands, 2003; Volume 13, p. 29.

5. Rodríguez, F.; Chauton, M.; Johnsen, G.; Andresen, K.; Olsen, L.M.; Zapata, M. Photoacclimation in phytoplankton: implications for biomass estimates, pigment functionality and chemotaxonomy. Mar. Biol. 2006, 148, 963-971.

6. Mangoni, O.; Carrada, G.C.; Modigh, M.; Catalano, G.; Saggiomo, V. Photoacclimation in Antarctic bottom ice algae: an experimental approach. Polar Biol. 2009, 32, 325-335.

7. Mackey, M.D.; Mackey, D.J.; Higgins, H.W.; Wright, S.W. CHEMTAX- a program for estimating class abundances from chemical markers: application to HPLC measurements of phytoplankton. Mar. Ecol. Progr. Ser. 1996, 144, 265-283.

8. Jeffrey, S.W.; Vesk, M. Introduction to marine phytoplankton and their pigment signatures. In Phytoplankton Pigments in Oceanography: Guidelines to Modern Methods; Jeffrey S.W., Mantoura R.F.C., Wright, S.W., Eds.; UNESCO Publishing: Paris, France, 1997; pp. 37-84.

9. Zapata, M.; Jeffrey, S.W.; Wright, S.W.; Rodríguez, F.; Garrido, J.L.; Clementson, L. Photosynthetic pigments in 37 species (65 strains) of Haptophyta: implications for oceanographyand chemotaxonomy. Mar. Ecol. Prog. Ser. 2004, 270, 83-102.

10. Yoshii, Y.; Takaichi, S.; Maoka, T.; Suda, S.; Sekiguchi, H.; Nakayama, T.; Inouye, I. Variation of siphonaxanthin series among the genus Nephroselmis (Prasinophyceae, Chlorophyta), including a novel methoxyl carotenoid. J. Phycol. 2005, 41, 827-834.

11. Wright, S.W.; Jeffrey, S.W. Pigment markers for phytoplankton production. In Marine Organic Matter: Biomarkers, Isotopes and DNA; Volkman, J.K., Ed.; Springer-Verlag: Berlin, Germany, 2006; pp. 71-104.

12. Latasa, M. Improving estimations of phytoplankton class abundances using CHEMTAX. Mar. Ecol. Prog. Ser. 2007, 329, 13-21.

13. Jeffrey, S.W. Application of pigment methods to oceanography. In: Phytoplankton Pigments in Oceanography: Guidelines to Modern Methods; Jeffrey S.W., Mantoura R.F.C., Wright, S.W., Eds.; UNESCO Publishing: Paris, France, 1997; p. 127.

14. Laza-Martinez, A.; Seoane, S.; Zapata, M.; Orive, E. Phytoplankton pigment patterns in a temperate estuary: from unialgal cultures to natural assemblages. J. Plankton Res. 2007, 29, 913-929.

15. Mangoni, O.; Modigh, M.; Mozetic, P.; Bergamasco, A.; Rivaro, P.; Saggiomo, V. Structure and photosynthetic properties of phytoplankton assemblages in a highly dynamic system, the Northern Adriatic Sea. Estuar. Coast. Shelf Sci. 2008, 77: 633-644.

16. Ras, J.; Claustre, H.; Uitz, J. Spatial variability of phytoplankton pigment distributions in the Subtropical South Pacific Ocean: comparison between in situ and predicted data. Biogeosciences 2008, 5, 353-369. 
17. Smith, W.O., Jr.; Tozzi, S.; DiTullio, G.R.; Dinnimand, M.; Mangoni, O.; Modigh, M.; Saggiomo, V. Phytoplankton photosynthetic pigments in the Ross Sea: patterns and relationships among functional groups. J. Mar. Systems 2010, 82: 177-185.

18. Anderson, D. M. Toxic algal blooms and red tides: a global perspective. In Red Tides: Biology, Environmental Science and Tosicology; Okaichi, T., Anderson, D.M., Nemoto, T., Eds.; Elsevier: New York, NY, USA, 1989; pp. 11-16.

19. Zingone, A.; Enevoldsen , H.O. The diversity of harmful algal blooms: a challenge for science and management. Ocean Coastal Manage 2000, 43, 725-748.

20. Masò, M.; Garcés, E. Harmful microalgae blooms (HAB); problematic and conditions that induce them. Mar. Pollut. Bull. 2006, 53, 620-630.

21. Zingone, A.; Siano, R.; D’Alelio, A.; Sarno, D. Potentially toxic and harmful microalgae from coastal waters of the Campania region (Tyrrhenian Sea, Mediterranean Sea). Harmful Algae 2006, 5, 321-337.

22. Smayda, T.J. Harmful algal blooms: Their ecophysiology and general relevance to phytoplankton blooms in the sea. Limnol. Oceanogr. 1997, 1137-1153.

23. Smayda, T.J.; Reynolds, C.S. Community Assembly in Marine Phytoplankton: Application of Recent Models to Harmful Dinoflagellate Blooms. J. Plankton Res. 2001, 23, 447-461.

24. Hallegraeff, G.M., Anderson, D.M., Cembella, A.D., Eds.; Manual on Harmful Marine Microalgae, Monographs on oceanographic methodology 11; UNESCO, Paris, France, 2004.

25. Pearson, L.; Mihali, T.; Moffitt, M.; Kellmann, R.; Neilan, B. On the Chemistry, Toxicology and Genetics of the Cyanobacterial Toxins, Microcystin, Nodularin, Saxitoxin and Cylindrospermopsin. Mar. Drugs 2010, 8, 1650-1680.

26. Ma, H.Y.; Krock, B.; Tillmann, U.; Cembella, A. Preliminary Characterization of Extracellular Allelochemicals of the Toxic Marine Dinoflagellate Alexandrium tamarense Using a Rhodomonas salina Bioassay. Mar. Drugs 2009, 7, 497-522.

27. Lefebvre, K.A.; Bill, B.D.; Erickson, A.; Baugh, K.A.; O'Rourke, L.; Costa, P.R.; Nance, S.; Trainer, V.L. Characterization of intracellular and extracellular saxitoxin levels in both field and cultured Alexandrium spp. samples from Sequim Bay, Washington. Mar. Drugs 2008, 6, 103-116.

28. Wang, D.Z. Neurotoxins from marine dinoflagellates: A brief review. Mar. Drugs 2008, 6, 349-371.

29. Landsberg, J.H. The effects of harmful algal blooms on aquatic organisms. Rev. Fish. Sci. 2002, 10, 113-390.

30. Backer, L.C.; Kirkpatrick, B.; Fleming, L.E.; Cheng ,Y.S.; Pierce, R.; Bean, J.A.; Clark, R.; Johnson, D.; Wanner, A.; Tamer, R.; Zhou, Y.; Baden, D.G. Occupational exposure to aerosolized brevetoxins during Florida red tide events: effects on a healthy worker population. Environ. Health Persp. 2005, 113, 644-649.

31. Pierce R.H.; Henry M.S. Harmful algal toxins of the Florida red tide (Karenia brevis): natural chemical stressors in South Florida coastal ecosystems. Ecotoxicology 2008, 17, 623-631.

32. Ramos, V.; Vasconcelos, V. Palytoxin and Analogs: Biological and Ecological Effects. Mar. Drugs 2010, 8, 2021-2037. 
33. Richlen, M.L.; Morton, S.L.; Jamali, E.A.; Rajan A.; Anderson D.M. The catastrophic 2008-2009 red tide in the Arabian gulf region, with observations on the identification and phylogeny of the fish-killing dinoflagellate Cochlodinium polykrikoides. Harmful Algae 2010, 9, 163-172.

34. Wiese, M.; D’Agostino, Paul, M.;. Mihali, T.K.; Moffitt, M.C.; Neilan, B.A. Neurotoxic Alkaloids: Saxitoxin and Its Analogs. Mar. Drugs 2010, 8, 2185-2211.

35. Hallegraeff, G.M. Harmful algal blooms: a global overview. In: Manual on Harmful Marine Microalgae, Monographs on oceanographic methodology 11; Hallegraeff, G.M., Anderson, D.M., Cembella, A.D., Eds.; UNESCO, Paris, France, 2004; pp. 25-50.

36. Bourdelais, A.; Tomas, C.R.; Narr, J.; Kubanek, J; Baden, D. A new fish-killing alga in coastal Delaware produces neurotoxins. Environ. Health Perspect. 2002, 110, 465-470.

37. Hallegraeff, G.M. A review of harmful algal blooms and their apparent global increase. Phycologia 1993, 32, 79-99.

38. Tomas, C.R.; Smayda, T.J. Red tide blooms of Cochlodinium polykrikoides in a coastal cove. Harmful Algae 2008, 7, 308-317.

39. Anderson, D.M. Harmful Algal Blooms and Ocean Observing Systems: Needs, Present Status and Future Potential. In Fisheries for Global Welfare and Environment; Memorial book of the 5th World Fisheries Congress, TERRAPUB, Tokyo, Japan, 2008; Tsukamoto, K., Kawamura, T., Takeuchi, T., Beard, T.D., Jr., Kaiser, M.J., Eds.; pp. 317-334.

40. Richardson, T.L.; Pinckney, J.L. Monitoring of the toxic dinoflagellate Karenia brevis using gyroxanthin-based detection methods. J. Appl. Phycol. 2004, 16, 315-328.

41. Gárate-Lizárraga, I.; Bustillos-Guzmán J.J.; Morquecho L.M.; Lechuga-Deveze C.H. First Outbreak of Cochlodinium polykrikoides in the Gulf of California. Harmful Algae News 2000, 21, 7.

42. Bustillos-Guzmán, J.; Gárate-Lizárraga, I.; López-Cortés, D.; Hernández-Sandoval, F. The use of pigment "fingerprints" in the study of harmful algal blooms. Rev. Biol. Trop. 2004, 52 (Suppl. 1), $17-26$.

43. Bowers, H.; Tengs, T.; Sayaka, G.; Tomas, C.R.; Ono, C.; Yoshimatsu, S.; Oldach, D. Development of real-time PCR assays for the detection of Chattonella species in culture and environmental samples. In Harmful Algae; Steidinger, K.A, Landsberg, J.H., Tomas, C.R., Vargo, G.A., Eds.; Florida Fish and Wildlife Conservation Commission, Florida Institute of Oceanography and Intergovernmental Oceanographic Commission: St. Petersburg, FL, USA, 2004; pp. 231-233.

44. Bowers, H.A.; Tomas, C.R.; Tengs, T.; Kempton, J. W.; Lewitus, A.J.; Oldach, D.W. 35 Raphidophyceae (Chadefaud ex Silva) systematics and rapid identification: sequence analysis and 36 real-time PCR analysis. J. Phycol. 2006, 42, 1333-1348.

45. Vidussi, F.; Claustre, H.; Bustillos-Guzman, J.; Cailliau, C.; Marty, J.-C. Determination of chlorophylls and carotenoids of marine phytoplankton: separation of chlorophyll a from divinylchlorophyll a and zeaxanthin from lutein. J. Plank Res. 1996, 18, 2377-2382.

46. Mantoura, R.F.C.; Repeta, D. In Phytoplankton Pigments in Oceanography: Guidelines to Modern Methods; Jeffrey, S.W., Mantoura, R.F.C., Wright, S.W., Eds.; UNESCO Publishing: Paris, France, 1997; pp. 407-428. 
47. Britton, G.; Liaaen-Jensen, S.; Pfander, H. Carotenoids Handbook; Birkhäuser Verlag: Basel, Switzerland, 2004; p. 238.

48. Andersen, R. In Algal Culturing Techniques; Elsevier Academic Press: San Diego, CA, USA, 2005 ; p. 578.

Samples Availability: Available from the authors.

(C) 2011 by the authors; licensee MDPI, Basel, Switzerland. This article is an open-access article distributed under the terms and conditions of the Creative Commons Attribution license (http://creativecommons.org/licenses/by/3.0/). 